\title{
Induction of release and up-regulated gene expression of interleukin (IL)-8 in A549 cells by serine proteinases Haiyan Wang, Yanshan Zheng and Shaoheng $\mathrm{He}^{*}$
}

Address: Allergy and Inflammation Research Institute, the Key Immunopharmacology Laboratory of Guangdong Province, Shantou University Medical College, Shantou 515031, China

Email: Haiyan Wang - hywang@stu.edu.cn; Yanshan Zheng - jzhengb@stu.edu.cn; Shaoheng He* - shoahenghe@hotmail.com

* Corresponding author

Published: 15 May 2006

BMC Cell Biology 2006, 7:22 doi:10.1/86/|47|-2/2I-7-22

This article is available from: http://www.biomedcentral.com/l47/-2/2I/7/22

(c) 2006 Wang et al; licensee BioMed Central Ltd.

This is an Open Access article distributed under the terms of the Creative Commons Attribution License (http://creativecommons.org/licenses/by/2.0), which permits unrestricted use, distribution, and reproduction in any medium, provided the original work is properly cited.
Received: 08 October 2005

Accepted: 15 May 2006

\begin{abstract}
Background: Hypersecretion of cytokines and serine proteinases has been observed in asthma. Since protease-activated receptors (PARs) are receptors of several serine proteinases and airway epithelial cells are a major source of cytokines, the influence of serine proteinases and PARs on interleukin (IL)-8 secretion and gene expression in cultured A549 cells was examined.

Results: A549 cells express all four PARs at both protein and mRNA levels as assessed by flow cytometry, immunofluorescence microscopy and reverse transcription polymerase chain reaction (PCR). Thrombin, tryptase, elastase and trypsin induce a up to 8, 4.3, 4.4 and 5.I fold increase in IL-8 release from A549 cells, respectively following $16 \mathrm{~h}$ incubation period. The thrombin, elastase and trypsin induced secretion of IL-8 can be abolished by their specific inhibitors. Agonist peptides of PAR-I, PAR-2 and PAR-4 stimulate up to $15.6,6.6$ and 3.5 fold increase in IL-8 secretion, respectively. Real time PCR shows that IL- 8 mRNA is up-regulated by the serine proteinases tested and by agonist peptides of PAR-I and PAR-2.
\end{abstract}

Conclusion: The proteinases, possibly through activation of PARs can stimulate IL-8 release from A549 cells, suggesting that they are likely to contribute to IL-8 related airway inflammatory disorders in man.

\section{Background}

Respiratory epithelium acts as the first tissue to meet inhaled pathogens and is capable of releasing inflammatory mediators and cytokines in response. Respiratory epithelial cells can synthesize and secrete a variety of proinflammatory cytokines such as IL-8, IL-1, IL-6, granulocyte-macrophage colony stimulating factor (GM-CSF) [1] and RANTES [2] which regulate cell behavior including growth, secretion, migration in physiological and pathological conditions.
The importance of serine proteinases in the development of airway diseases has been emphasized in recent years. Of particular importance is that the potential role of tryptase [3] thrombin [4] and elastase [5] in the development of asthma, in which these serine proteinases were not only been over-secreted $[4,6,7]$, but also found to play a role in induction of cytokine hypersecretion in airways $[8,9]$. However, the potential mechanism, through which these serine proteinases carry out their actions in respiratory tract, remains unclear. Since increased level of IL- 8 in the airways reported to be closely correlated to asthma [10], we investigated the effect of tryptase, thrombin, trypsin, 

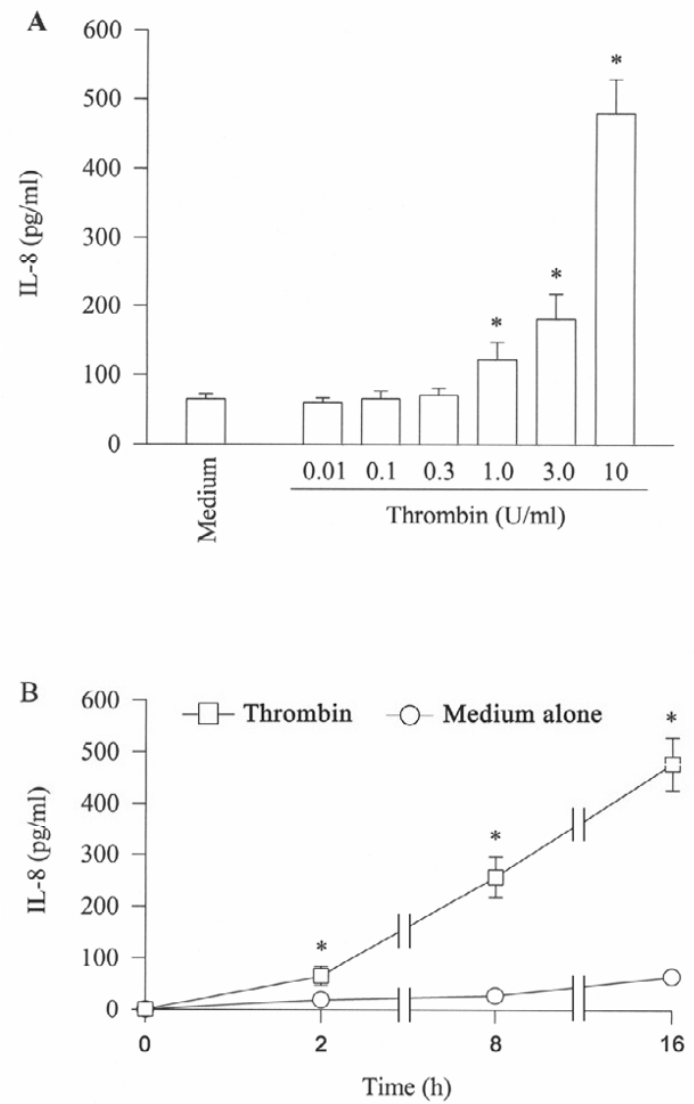

\section{Figure I}

Effect of thrombin on the release of IL-8 from A549 cells. Cells were incubated $(\mathbf{A})$ with various concentrations of thrombin at $37^{\circ} \mathrm{C}$ for $16 \mathrm{~h}$, or $(\mathbf{B})$ with $10 \mathrm{U} / \mathrm{ml}$ of thrombin for $2 \mathrm{~h}, 8 \mathrm{~h}$ and $16 \mathrm{~h}$. Values shown are mean \pm SE for $5 \mathrm{sep}-$ arate experiments. $* P<0.05$ compared with the response to medium alone control.

and elastase on IL-8 secretion and gene expression in A549 cells, a type II alveolar epithelial cell line from human adenocarcinoma, in the present study.

In recent years, PARs have been identified as receptors for serine proteinases. Among them, PAR-1 is a receptor of thrombin and trypsin [11]; PAR-2 is a receptor of trypsin, tryptase [12] and elastase [9]; PAR-3 [13] and PAR-4 [14] are receptors of thrombin. Activation of PARs could profoundly alter secretion ability of numerous cell types such as histamine release from human mast cells [15], IL-6 release from airway epithelial cells [8], IL-1 release from fibroblast [16], and IL-8 release from human oral epithelial cells [17]. We therefore investigated the effect of the agonists of all four types of PARs on IL- 8 release from A549 cells in the current study. Since expression of PARs on A549 cells is crucial for the understanding of actions of the serine proteinases tested, we also investigated the expression PAR-1, PAR-2, PAR-3 and PAR-4 on A549 cells with immunocytochemical techniques and reverse transcription polymerase chain reaction (RT-PCR) in the present study.

\section{Results \\ Induction of IL-8 release by serine proteinases}

Thrombin at concentrations of $1-10 \mathrm{U} / \mathrm{ml}$ provokes a concentration dependent release of IL- 8 from A549 cells following $16 \mathrm{~h}$ incubation period. Approximately 8 fold increase in IL- 8 release is observed at $16 \mathrm{~h}$ following incubation with $10 \mathrm{U} / \mathrm{ml}$ thrombin (Figure 1A). The time course study shows that increased release of IL-8 induced by thrombin begins within $2 \mathrm{~h}$, and lasts at least to $16 \mathrm{~h}$ (Figure 1B).

At the concentrations from 1 to $300 \mathrm{ng} / \mathrm{ml}$, trypsin is able to stimulate a 'bell shape' release of IL-8 from A549 cells following $16 \mathrm{~h}$ incubation period. The maximum release of 5.1 fold is observed when $3 \mathrm{ng} / \mathrm{ml}$ of trypsin was added to A549 cells. At the time of $8 \mathrm{~h}$, however, a dose dependent release of IL-8 from A549 cells is achieved with 100 and $300 \mathrm{ng} / \mathrm{ml}$ trypsin. Small but nevertheless significant release of IL- 8 is also observed with $300 \mathrm{ng} / \mathrm{ml}$ trypsin following $2 \mathrm{~h}$ incubation (Figure 2). Also in Figure 2, it is clearly observed that the basal accumulated secretion of IL- 8 from A549 cells is time dependent with $2.7 \pm 0.7,173$ \pm 54 and $329 \pm 91 \mathrm{pg} / \mathrm{ml}$ being secreted following 2, 8 and $16 \mathrm{~h}$ incubation periods, respectively. Trypsin at concentration of $300 \mathrm{ng} / \mathrm{ml}$ fails to stimulate IL-10, IL-16, IL-17 and IL-18 secretion from A549 cells following $8 \mathrm{~h}$ incubation period (data not shown).

Tryptase at the concentrations from 0.125 to $2 \mu \mathrm{g} / \mathrm{ml}$ induces a concentration dependent IL-8 secretion from A549 cells. Approximately 4.3 fold increase in release of IL- 8 is observed when $2 \mu \mathrm{g} / \mathrm{ml}$ of tryptase was incubated with cells for $16 \mathrm{~h}$, and as little as $0.25 \mu \mathrm{g} / \mathrm{ml}$ tryptase is able to provoke a significant release of IL- 8 from A549 cell at $16 \mathrm{~h}$ following incubation (Figure $3 \mathrm{~A}$ ). Time course study reveals that increased release of IL- 8 induced by tryptase begins within $2 \mathrm{~h}$, and lasts at least to $16 \mathrm{~h}$ (Figure $3 \mathrm{~B})$. Elastase, however, only at the concentrations of 0.1 and $0.3 \mu \mathrm{g} / \mathrm{ml}$ elicits significant release of IL- 8 following $16 \mathrm{~h}$ incubation period, and the quantity of IL- 8 released from A549 cells in response to $0.3 \mu \mathrm{g} / \mathrm{ml}$ elastase is similar to that induced by $2 \mu \mathrm{g} / \mathrm{ml}$ of tryptase (Figure $3 \mathrm{~A}$ ). Time course study shows that elastase induced release of IL- 8 occurs after $8 \mathrm{~h}$ incubation and maintains at least to $16 \mathrm{~h}$ (Figure $3 \mathrm{~B}$ ). 


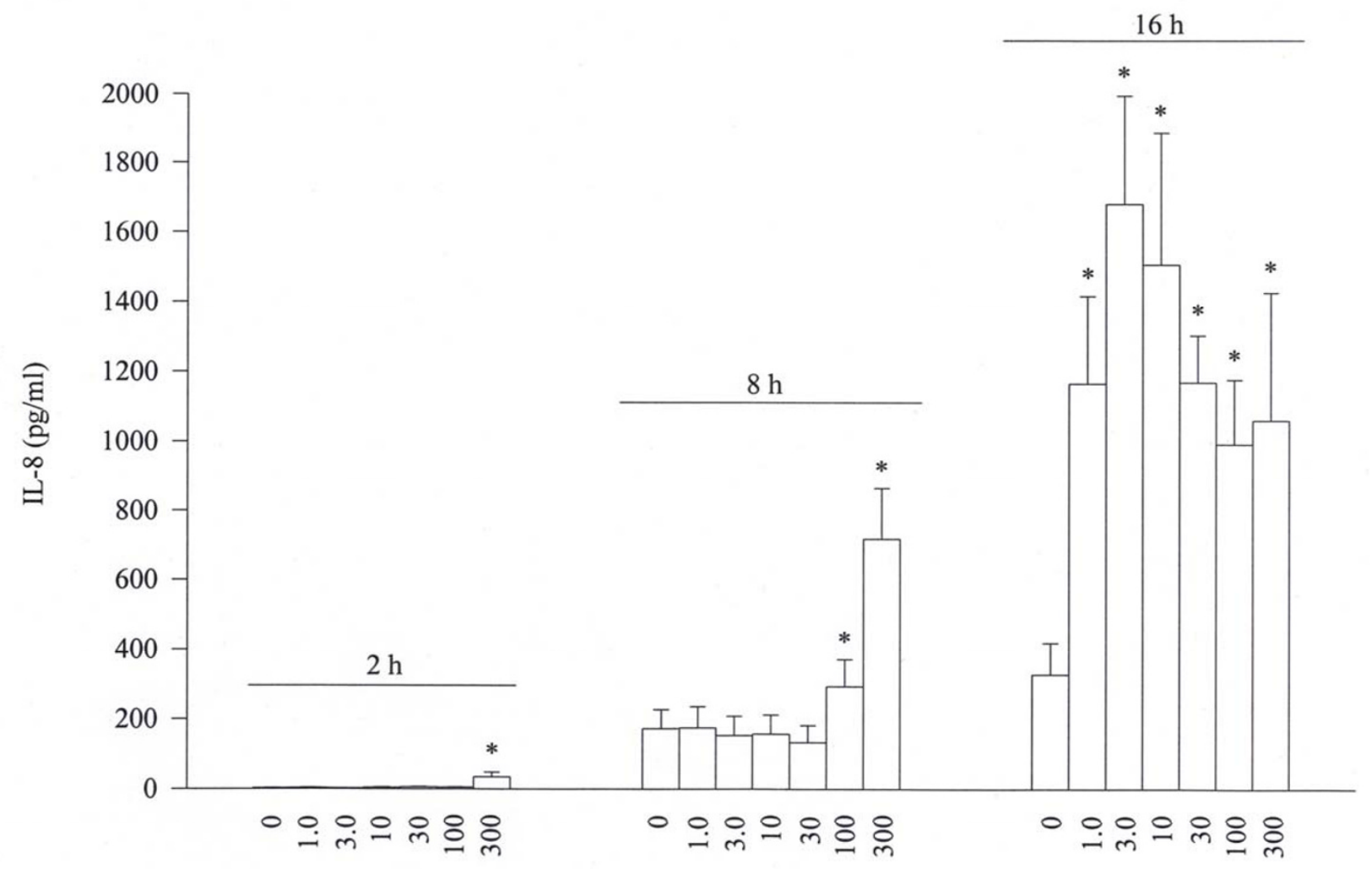

Trypsin concentration (ng/ml)

\section{Figure 2}

Effect of trypsin on the release of IL-8 from A549 cells. Cells were incubated with various concentrations of trypsin at $37^{\circ} \mathrm{C}$ for $2 \mathrm{~h}, 8 \mathrm{~h}$ or $16 \mathrm{~h}$. Values shown are mean \pm SE for 5 separate experiments. $* p<0.05$ compared with the response to medium alone control.

\section{Inhibition of IL-8 release induced by proteinases by their inhibitors}

Hirudin, a specific thrombin inhibitor is able to inhibit thrombin-induced secretion of IL- 8 at both 2 and $16 \mathrm{~h}$ following incubation. The maximum inhibition of approximately $89 \%$ is observed when $10 \mathrm{U} / \mathrm{ml}$ of hirudin was added to cells for $16 \mathrm{~h}$ (Table 2 ). Similarly, specific trypsin inhibitors SBTI and $\alpha_{1}$-antitrysin are able to completely abolish trypsin-induced secretion of IL- 8 at both 8 and 16 $\mathrm{h}$ following incubation (Table 3 ). It is observed also that MSACK, an inhibitor of elastase completely abrogates elastase induced release of IL-8 (Table 4). In contrast, inhibitors of tryptase, benzamine and leupeptine are only able to inhibit tryptase induced IL- 8 secretion by $47.5 \%$ and $6.5 \%$, respectively following $16 \mathrm{~h}$ incubation (Table 4). Hirudin (Table 2), SBTI, and $\alpha_{1}$-antitrysin (Table 3 ), benzamidine, leupeptine and MSACK (Table 4) alone at the concentrations tested have little effect on IL- 8 secretion from A549 cells.

\section{Expression of PARs by $A 549$ cells}

FACS analysis shows that A549 cells express all four PARs regardless they are permeabilized or not (Figure 4A). Immunofluorescent cell staining shows that PAR-2 seems mainly stained on the membrane surface of A549 cells, whereas PAR-1, PAR-3 and particularly PAR-4 predominately stained in cytoplasm (Figure 4B). An agarose gel electrophoresis revealed that A549 cells express mRNAs for all four PARs (Figure 4C). The amplified RT-PCR products of PAR-1, PAR-2, PAR-3 and PAR-4 mRNAs were sequenced and they all correspond to published sequences of PAR genes (data not shown).

\section{Induction of IL-8 release by agonists of PARs}

SFLLR-NH $\mathrm{N}_{2}$ a specific PAR-1 agonist peptide stimulats a concentration dependent secretion of IL-8 from A549 cells following $16 \mathrm{~h}$ incubation (Figure 5A), whereas its reverse peptide RLLFS- $\mathrm{NH}_{2}$ has no effect on IL- 8 release. The maximum release of IL- 8 is 15.6 fold induced by 300 
$\mu \mathrm{M}$ of SFLLR- $\mathrm{NH}_{2}$ following $16 \mathrm{~h}$ incubation period (Figure $5 \mathrm{~A}$ ). However, TFRGAP-NH $\mathrm{N}_{2}$, an agonist peptide of PAR-3 and its reverse peptide PAGRFT- $\mathrm{NH}_{2}$ at concentrations $0.1,1,10$ and $100 \mu \mathrm{M}$ do not show any influence on IL-8 release from A549 cells following $16 \mathrm{~h}$ incubation period (data not shown). The time course study shows that SFLLR- $\mathrm{NH}_{2}$ induced release of IL-8 occurs after $8 \mathrm{~h}$ incubation and sustains at least until $16 \mathrm{~h}$ (Figure 5B).

While SLIGKV-NH ${ }_{2}$ and tc-LIGRLO-NH ${ }_{2}$, two specific agonists of PAR-2 induce concentration dependent secretion of IL-8 from A549 cells following 8 and $16 \mathrm{~h}$ incubation periods (Figure $6 \mathrm{~B}, 6 \mathrm{C}$ ) only tc-LIGRLO- $\mathrm{NH}_{2}$ is able to stimulate IL-8 release at $2 \mathrm{~h}$ (Figure 6A). The maximum release of IL- 8 is approximately 79 and 6.6 fold over baseline induced by $100 \mu \mathrm{M}$ of tc-LIGRLO-NH ${ }_{2}$ at $2 \mathrm{~h}$ and 100 $\mu \mathrm{M}$ of SLIGKV-NH${ }_{2}$ at $8 \mathrm{~h}$, respectively. VKGILS- $\mathrm{NH}_{2}$ has little effect on IL-8 release, but tc-OLRGIL- $\mathrm{NH}_{2}$ appears to induce a significant release IL-8 from A549 cells. However, the extent of release of IL-8 induced by tc-OLRGIL$\mathrm{NH}_{2}$ is much less than that induced by tc-LIGRLO- $\mathrm{NH}_{2}$ (Figure 6). SLIGKV-NH $\mathrm{N}_{2}$ and tc-LIGRLO-NH $\mathrm{N}_{2}$ at concentration of $10 \mu \mathrm{M}$ fail to stimulate IL-10, IL-16, IL-17, and IL-18 secretion from A549 cells following $8 \mathrm{~h}$ incubation period (data not shown).

At a concentration of $10 \mu \mathrm{M}$, GYPGQV-NH ${ }_{2}$, an agonist peptide of PAR-4 induces a 3.5 fold increase in IL- 8 release from A549 cells. However, at a higher concentration (100 $\mu \mathrm{M})$, it stimulates less IL-8 secretion (Figure 7A). VQGPYG-NH ${ }_{2}$, a reverse peptide of GYPGQV-NH ${ }_{2}$, at the concentrations tested does not show any influence on IL-8 release (Figure 7A). The time course study shows that GYPGQV-NH $\mathrm{N}_{2}$ induced release of IL-8 occurs after $8 \mathrm{~h}$ incubation and sustains at least until $16 \mathrm{~h}$ (Figure 7B).

\section{Effect of serine proteinases and agonists of PARs on expression of IL-8 mRNA in A549 cells}

Thrombin, trypsin, tryptase and elastase stimulate an increase in expression of IL-8 mRNA in A549 cells when they were incubated with the cells. However, the tryptase induced up-regulation of expression of IL-8 mRNA only lasts for $2 \mathrm{~h}$, whereas thrombin, trypsin (declined after 8 h) and elastase provoked expression of IL- 8 mRNA continues until $16 \mathrm{~h}$. Up to $6.8,22.3,9.9$ and 7.8 fold increase in expression of IL-8 mRNA is observed with thrombin, trypsin, tryptase and elastase, respectively following incubation with A549 cells (Figure 8). Dramatically enhanced expression of IL-8 mRNA is found when SFLLR-NH ${ }_{2}$, SLIGKV-NH $\mathrm{N}_{2}$ or tc-LIGRLO-NH $\mathrm{N}_{2}$ was incubated with A549 cells for $2 \mathrm{~h}$. At 8 and $16 \mathrm{~h}$ following incubation, however, IL-8 mRNA expression induced by SFLLR-NH ${ }_{2}$, SLIGKV$\mathrm{NH}_{2}$ or tc-LIGRLO- $\mathrm{NH}_{2}$ is greatly decreased (Figure 8). GYPGQV-NH $\mathrm{N}_{2}$ and TFRGAP- $\mathrm{NH}_{2}$ at $100 \mu \mathrm{M}$ has little influence on IL-8 mRNA expression in A549 cells (Figure
8). At the concentration of $100 \mu \mathrm{M}$, RLLFS- $\mathrm{NH}_{2}$, VKGILS$\mathrm{NH}_{2}$, tc-OLRGIL-NH $\mathrm{N}_{2}$, PAGRFT- $\mathrm{NH}_{2}$ and VQGPYG-NH $\mathrm{N}_{2}$, the reverse peptides of agonists of PARs have little effect on IL-8 mRNA expression in A549 cells (data not shown).

\section{Discussion}

It is demonstrated that human serine proteinases including thrombin, tryptase, elastase and trypsin are potent stimuli of IL-8 secretion from A549 cells, which suggests that they are likely to play a role in IL-8 related airway inflammatory disorders such as asthma, chronic obstructive pulmonary disease and cystic fibrosis.

As little as $5.6 \mathrm{nM}$ of thrombin is able to stimulate approximately 2 fold increase in IL- 8 secretion, and $56 \mathrm{nM}$ of thrombin induces 8 fold increase in IL- 8 release, indicating that this proteinase is a potent secretagogue of IL-8 release from A549 cells. Human mast cell tryptase, an established mediator of inflammation [18] at a concentration as low as $3.7 \mathrm{nM}$ induces twice more IL-8 secretion over baseline release, and trypsin, a potential mediator of airway inflammation [19] at a concentration of $0.042 \mathrm{nM}$ provokes approximately 3 fold increase in IL- 8 secretion from A549 cells, suggesting that tryptic enzyme in airways may play a role in stimulation of IL-8 hypersecretion from airway epithelium. Similarly, elastase, a well-established mediator of airway inflammation at a concentration of $10.2 \mathrm{nM}$ elicits 4 .4-fold increase in IL-8 release, indicating that it is a potent secretagogue of IL-8 release from A549 cells as well. At a concentration of $345 \mathrm{nM}$, elastase was also found to be able to induce IL- 8 and MCP-1 secretion from human gingival fibroblasts [9]. However, at the concentrations higher than $62.5 \mathrm{nM}$ elastase could disarm PAR-2 within 10 min following incubation with human lung epithelial cells [20]. These findings suggest that elastase at lower concentrations induce cytokine release from A549 cells, but at higher concentrations may inactivate PAR-2 on human lung epithelial cells including A549 cells. It was impossible for us to examine the effect of elastase at the concentrations higher than $62.5 \mathrm{nM}$ with our experimental system as at the concentration of $0.6 \mu \mathrm{g} /$ $\mathrm{ml}(20.4 \mathrm{nM})$, elastase was able to dissociate A549 cells from plate after $8 \mathrm{~h}$ incubation and the suspended cells died soon after (assessed by trypan blue staining). This phenomenon may explain the reason for which elastase at the concentration of $0.6 \mu \mathrm{g} / \mathrm{ml}$ fails to enhance IL- 8 release. The similar phenomenon is also observed with trypsin at the concentrations higher than $1 \mu \mathrm{g} / \mathrm{ml}$. These findings implicate that the detachment of bronchial epithelium observed in chronic airway inflammation may result from the hydrolytic activities of elastase and trypsin. Time course study shows that IL- 8 release induced by thrombin, tryptase and trypsin initiates within $2 \mathrm{~h}$ following incubation, whereas the response to elastase occurs only after $8 \mathrm{~h}$ incubation period. This indicates that 
Table I: Primer sequences for PARs

\begin{tabular}{|c|c|c|c|}
\hline Primer & & Sequence & Size of product (bp) \\
\hline \multirow[t]{2}{*}{ PAR-I } & sense & 5'-CAGCTCCTGGCTGACACTCTTTGTC-3' & 500 \\
\hline & antisense & 5'-CGAGCAGGGTTTCATTGAGCACAT-3' & \\
\hline \multirow[t]{2}{*}{ PAR-2 } & sense & 5'-GCAGCCTCTCTCTCCTGCAGTGG-3' & 461 \\
\hline & antisense & 5'-CTGAGGCAGGTCATGAAGAGAATGG-3' & \\
\hline \multirow[t]{2}{*}{ PAR-3 } & sense & 5'-GGCTGGACAGGAGCCACGAT-3' & 403 \\
\hline & antisense & 5'-AGCGGTTGATGCTGATGCAGG-3' & \\
\hline \multirow[t]{3}{*}{ PAR-4 } & RT & 5'-TGAGTAGCTGGGATTACAG-3' & 542 \\
\hline & sense & 5'-AACCTCTATGGTGCCTACGTGC-3' & \\
\hline & antisense & 5'- CCAAGCCCAGCTAATTTTTG-3' & \\
\hline \multirow[t]{2}{*}{$\beta$-actin } & sense & 5'-GTTGCGTTACACCCTTTCTT-3' & 148 \\
\hline & antisense & 5'-ACCTTCACCGTTCCAGTTT-3' & \\
\hline
\end{tabular}

elastase and the other proteinases tested may adopt different mechanisms in induction of IL-8 release from A549 cells. The concentrations of tryptase and elastase used in the present study should be achievable under pathological conditions as the level of tryptase in asthmatic bronchial alveolar lavage fluid was $13.2 \mathrm{ng} / \mathrm{ml}$ [21] and the levels of elastase in asthmatic and cystic fibrosis sputum were 27 and $466 \mathrm{ng} / \mathrm{ml}$, respectively [22]. While information on the levels of thrombin and trypsin in respiratory fluids are not available, a report described that trypsin-like activity was $46.9 \mathrm{mU} / \mathrm{ml}$ in mucoid sputum from patients with asthma [23] might implicate that the concentrations of thrombin and trypsin used in the current study ought to be achievable in the inflammatory airways.

A549 cells have been reported to secrete some $10 \mathrm{pg} / \mathrm{ml}$ of elafin and $3 \mathrm{ng} / \mathrm{ml}$ of secretory leukocyte protease inhibitor (SLPI) following $24 \mathrm{~h}$ incubation [24]. This concentration of elafin, an inhibitor of elastase should not affect the action of elastase on A549 cells, but the concentrations of SLPI, an inhibitor of trypsin and elastase may reduce the stimulatory action of the lower concentrations of trypsin or elastase on A549 cells.

Table 2: Effect of hirudin on IL-8 release from A549 cells induced by thrombin

\begin{tabular}{lll}
\hline Compound $(\mathrm{U} / \mathrm{ml})$ & \multicolumn{2}{c}{$\mathrm{IL}-8$ released $(\mathrm{pg} / \mathrm{ml})$} \\
$16 \mathrm{~h}$
\end{tabular}

Data shown are mean \pm SE for five separate experiments. Thrombin, hirudin, and thrombin with hirudin were added to cells for $2 \mathrm{~h}$ or 16 h. $* P<0.05$ compared with the corresponding concentration of thrombin alone.
Hirudin inhibites approximately $87 \%$ thrombin induced IL- 8 secretion; SBTI and $\alpha_{1}$-antitrypsin completely abolish trypsin induced IL- 8 secretion and MSACK eliminats $97 \%$ elastase induced IL-8 secretion, suggesting strongly that
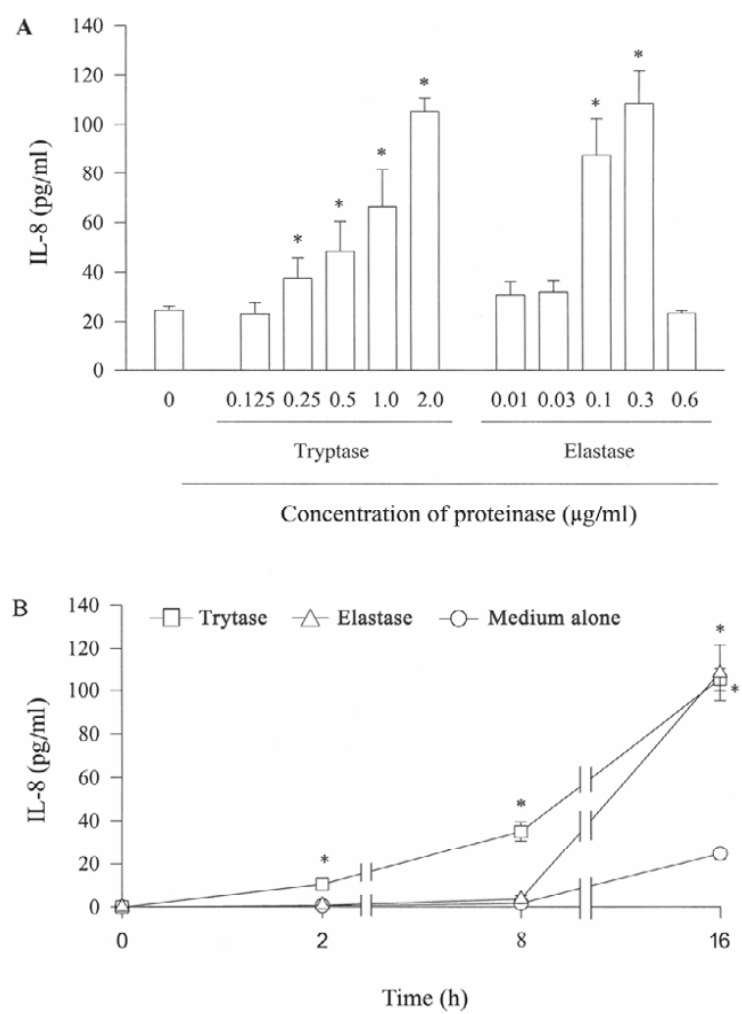

Figure 3

Effect of tryptase and elastase on the release of IL-8 from A549 cells. Cells were incubated with various concentrations of tryptase or elastase at $37^{\circ} \mathrm{C}$ for $16 \mathrm{~h}(\mathrm{~A})$, or with $2 \mu \mathrm{g} / \mathrm{ml}$ tryptase or $0.3 \mu \mathrm{g} / \mathrm{ml}$ elastase for $2 \mathrm{~h}, 8 \mathrm{~h}$ and $16 \mathrm{~h}(\mathrm{~B})$. Values shown are mean \pm SE for 5 separate experiments. $* P<$ 0.05 compared with the response to medium alone control. 
Table 3: Effect of trypsin inhibitors on IL-8 release from A549 cells induced by trypsin

\begin{tabular}{|c|c|c|}
\hline \multirow{2}{*}{ Compound $(\mu \mathrm{g} / \mathrm{ml})$} & \multicolumn{2}{|c|}{ IL-8 released $(\mathrm{pg} / \mathrm{ml})$} \\
\hline & $8 \mathrm{~h}$ & $16 \mathrm{~h}$ \\
\hline Medium alone & $173 \pm 54$ & $581 \pm 91$ \\
\hline SBTI 10 & $154 \pm 47$ & $631 \pm 102$ \\
\hline SBTI 30 & $194 \pm 52$ & $646 \pm 100$ \\
\hline$\alpha_{1}-\mathrm{AT} 10$ & nd & $505 \pm 105$ \\
\hline Trypsin 0.1 & $294 \pm 78$ & $993 \pm 185$ \\
\hline Trypsin $0.1+$ SBTI 10 & $176 \pm 47^{*}$ & $567 \pm 110 *$ \\
\hline Trypsin $0.1+$ SBTI 30 & $173 \pm 49 *$ & $590 \pm 120 *$ \\
\hline Trypsin $0.1+\alpha_{1}$-AT 10 & nd & $556 \pm 133^{*}$ \\
\hline Trypsin 0.3 & $718 \pm 147$ & $1061 \pm 366$ \\
\hline Trypsin $0.3+$ SBTI 10 & $158 \pm 45^{*}$ & $543 \pm 122 *$ \\
\hline Trypsin $0.3+$ SBTI 30 & $256 \pm 67^{*}$ & $654 \pm|4| *$ \\
\hline Trypsin $0.3+\alpha_{1}$-AT 10 & nd & $579 \pm|3| *$ \\
\hline
\end{tabular}

Data shown are mean \pm SE for five separate experiments. Trypsin, inhibitor, and trypsin with inhibitor were added to cells for $8 \mathrm{~h}$ or 16 h. $* P<0.05$ compared with the corresponding concentration of trypsin alone. $\alpha_{1}-\mathrm{AT}=\alpha_{1}$-antitrypsin, SBTI = soybean trypsin inhibitor, nd $=$ not done.

the actions of these proteinases on A549 cells are dependent upon their intact catalytic sites. Since the known substrates of these proteinases on cells are PARs, the expression of PARs on A549 cells was investigated in the present study. To our surprise, benzamidine and leupeptine at a concentration of $30 \mu \mathrm{g} / \mathrm{ml}$ (a quite high concentration for the study on cells based on our previous work [15] are only able to inhibit tryptase induced IL-8 secretion by $47.5 \%$ and $6.5 \%$, which suggests that IL- 8 secretion induced by tryptase may not depend on its enzymatic activity, and there may be a receptor other than PARs being involved in the process. The similar findings on tryptase were observed previously in other studies [25]. However, to our knowledge, this is the first work examining the effects of thrombin, trypsin, tryptase and elastase

Table 4: Effect of the inhibitors of tryptase or elastase on tryptase or elastase induced release of IL-8 from A549 cells

\begin{tabular}{ll}
\hline Compound $(\mu \mathrm{g} / \mathrm{ml})$ & $\mathrm{IL}-8$ released $(\mathrm{pg} / \mathrm{ml})$ \\
\hline Medium alone & $24.6 \pm 1.5$ \\
Tryptase 2.0 & $105.2 \pm 5.3^{*}$ \\
Elastase 0.3 & $108.4 \pm 13.2^{*}$ \\
Benzamidine 30 & $37.6 \pm 4.4$ \\
Leupeptine 30 & $27.4 \pm 5.6$ \\
MSACK 30 & $22.1 \pm 4.3$ \\
Tryptase $2.0+$ Benzamidine 30 & $66.9 \pm 4.8^{\dagger}$ \\
Tryptase $2.0+$ Leupeptin 30 & $100 \pm 1.7$ \\
Elastase $0.3+$ MSACK 30 & $26.9 \pm 3.6^{\dagger}$
\end{tabular}

Data shown are mean \pm SE for five to six separate experiments.

Stimulus, inhibitor, or stimulus with inhibitor was incubated with cells for 16 h. $* P<0.05$ compared with the response to medium alone; $t P$ $<0.05$ compared with the corresponding stimulus alone. on IL-8 release from airway epithelial cells under the same conditions.

It has been reported that a number of human cell types express more than one member of PAR family. Thus, platelets express PAR-1 and PAR-4 genes [14,26], endothelial cells express PAR-1, PAR-2, and possibly PAR$3[13,27]$, fibroblast express PAR-1, PAR-2, PAR-3 and PAR-4 genes [28], smooth muscle cell express PAR-1, PAR2, and PAR-3 genes [29] and respiratory epithelial cells express PAR-1, PAR-2, PAR-3 and PAR-4 genes and possibly proteins [8]. In the present study, we find that A549 cells express all four PARs at both protein and mRNA levels. Since expression of the PARs was observed under both permeabilized and non-permeabilized conditions, it is most likely that all these four PARs are located in both the cytoplasma and the plasma membrane surface of the cells.

The PAR family consists of a group of four G protein-coupled receptors including PAR-1, PAR-2, PAR-3 and PAR-4. They share a unique mechanism of activation involving the proteolytic cleavage of the receptor by serine proteinases to unmask a new $\mathrm{N}$-terminal sequence, the so-called "tethered ligand" that autoactivates the receptor [30]. Thus, thrombin and trypsin cleavage PAR-1 within the amino-tail (LDPR ${ }^{41} \downarrow S^{42}$ FLLRN, where $\downarrow$ denotes cleavage), trypsin, tryptase and elastase cleavages PAR-2 at the site of SKGR ${ }^{34} \downarrow S^{35}$ LIGKV, thrombin also cleavages PAR-3 at the site LPIK ${ }^{38} \downarrow T^{39}$ FRGAP and PAR- 4 at PAPR ${ }^{47} \downarrow G^{48}$ YPGQV [31]. Synthetic receptor-activating peptides corresponding to the new amino termini of the cleaved receptors can also activate PARs [11]. Thus, SFLLR-NH $\mathrm{N}_{2}$ [11], SLIGKV-NH [32] and tc-LIGRLO-NH $\mathrm{NH}_{2}$ [33], TFRGAP- $\mathrm{NH}_{2}$ [34], GYPGQV-NH $\mathrm{N}_{2}$ [35] represented agonists of PAR-1, PAR-2, PAR-3 and PAR-4, respectively in the current study. For comparison, their reverse peptides were used as controls.

SFLLR-NH ${ }_{2}$, tc-LIGRLO-NH ${ }_{2}$, SLIGKV-NH $\mathrm{N}_{2}$ and GYPGQV$\mathrm{NH}_{2}$ stimulates approximately 15.6, 79, 6.6, and 3.5 fold increase in release of IL-8, implicating that there are appropriate mechanisms to carry out IL-8 release process in response to PAR-1, PAR-2 and PAR-4 activation in A549 cells. However, A549 cells do not show any response (in terms of IL-8 release) to PAR-3 activation. Activation of A549 cells to release IL-8 by agonists of PARs indicates that the actions of thrombin, tryptase, elastase and trypsin on A549 cells are most likely carried out through hydrolytic cleavage of $\mathrm{N}$-termini of PARs. The time course shows that the influence of agonists of PAR-1 and PAR-2 on A549 cells initiates within $2 \mathrm{~h}$ following incubation, but the action of agonist of PAR- 4 on cells appears only after $8 \mathrm{~h}$ incubation. These observations suggest that the actions of thrombin on A549 cells are mainly (if not all) carried out through PAR-1, but not PAR-4, whereas the influence of trypsin on cells is most likely through both 
A
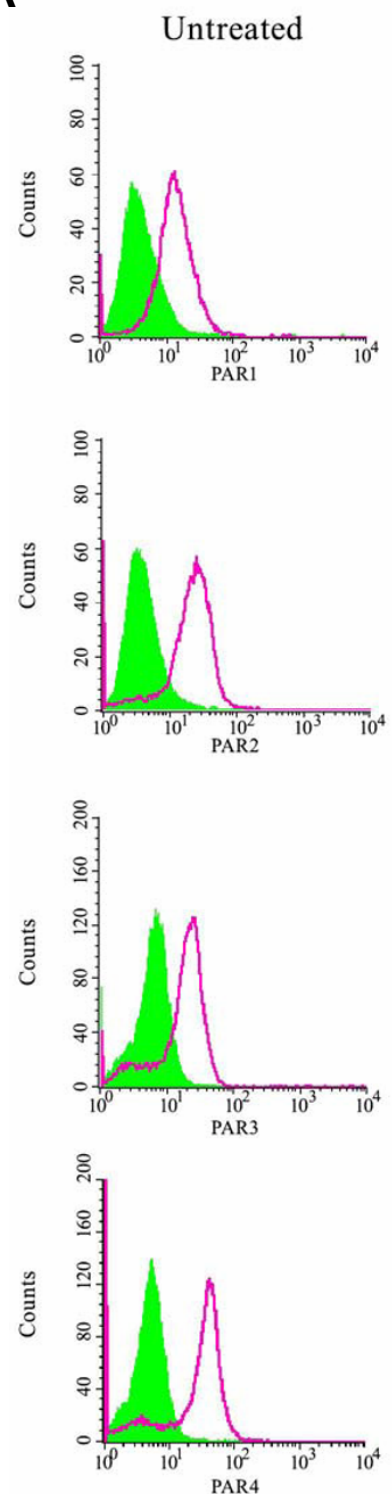

Triton $\mathrm{x}-100$ treated
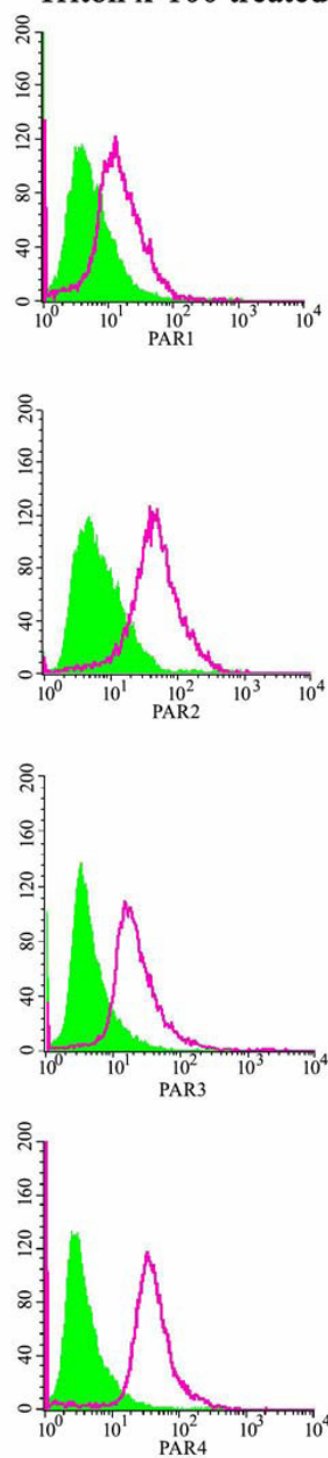

B
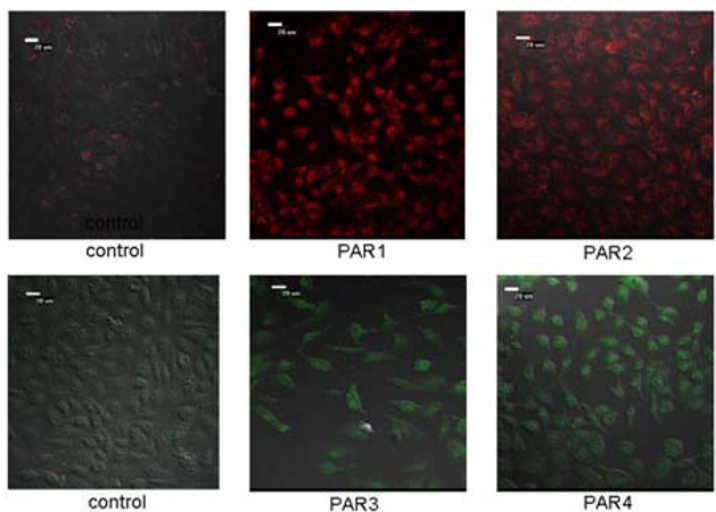

C

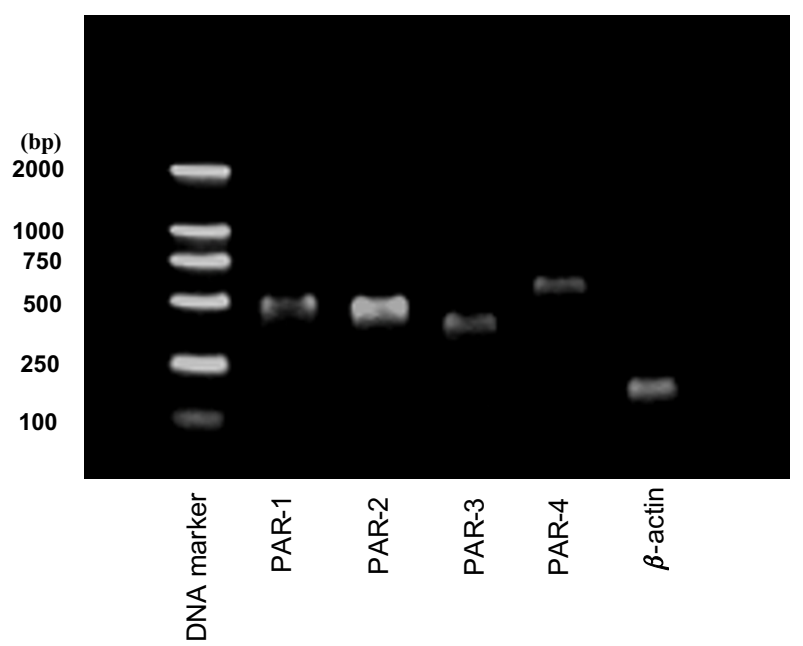

Figure 4

Analysis of expression of PARs on A549 cells by flow cytometry (A), Immunofluorescent microscopy (B) and RT-PCR (C). For PAR-I and PAR-2 labeling, cells were incubated with PE-conjugated mouse anti-human PAR-I monoclonal antibody and FITCconjugated mouse anti-human PAR-2 monoclonal antibody for $30 \mathrm{~min}$ on ice. For PAR-3 and PAR-4 labeling, cells were incubated with rabbit anti-human PAR-3 or PAR-4 polyclonal antibodies for $30 \mathrm{~min}$ on ice followed by addition of FITC-conjugated goat anti-rabbit polyclonal antibodies. To detect cytoplasmic PARs, A549 cells were permeabilized with $0.2 \%$ Triton X-100 for $5 \mathrm{~min}$ at room temperature before analysis. Immunofluorescent microscopy was performed with a laser scanning confocal microscope. For RT-PCR analysis of expression of mRNAs of PARs in A549 cells, the gene products of PARs were separated in I.5\% agarose gels, stained with SYBR Green I Nucleic Acid Gel Stain and photographed under UV light. Lane I-6 represented DNA marker, PAR-I (500 bp), PAR-2 (46I bP), PAR-3 (403 bP), PAR-4 (542 bp) and $\beta$-actin ( 148 bp), respectively.

PAR-1 and PAR-2. It is hard to understand the slower response of cells to elastase and at least partially enzymatic activity independent actions of tryptase on A549 cells. These obviously require further investigation. Using various concentrations of agonist peptides of PARs to stimulate A549 cells may better reflect the actions of these peptides on the cells, which reinforces the previous finding [8]. 

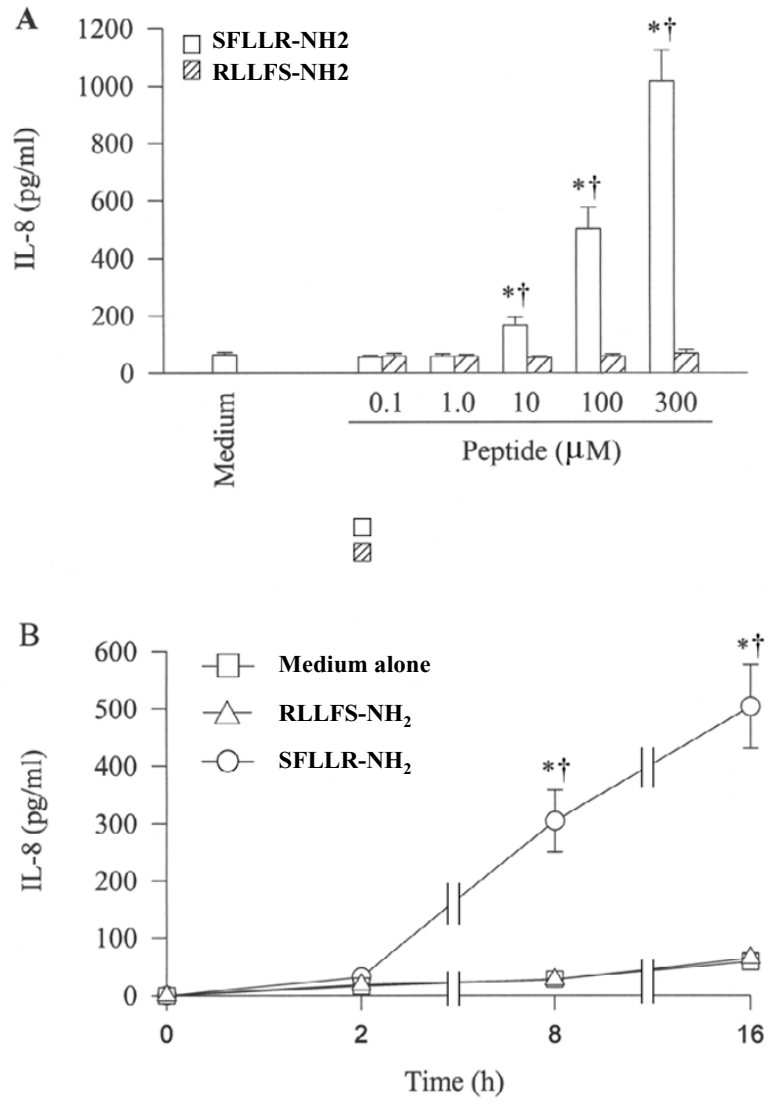

Figure 5

Effect of SFLLR-NH $\mathrm{NH}_{2}$, an agonist peptide of PAR-I and its reverse peptide RLLFS-NH ${ }_{2}$ on IL- 8 release from A549 cells. Cells were incubated $(\mathbf{A})$ with various concentrations of SFLLR-NH $\mathrm{NH}_{2}$ (open bar) or RLLFS-NH $\mathrm{NH}_{2}$ (hatched bar) at $37^{\circ} \mathrm{C}$ for $16 \mathrm{~h}$ or (B) with $100 \mu \mathrm{M}$ of SFLLR-NH $\mathrm{NH}_{2}$ and RLLFS-NH for $2 \mathrm{~h}, 8 \mathrm{~h}$ and $16 \mathrm{~h}$. Values shown are Mean \pm SE for five separate experiments performed in duplicate. $* P<0.05 \mathrm{com}-$ pared with the response to medium alone control; $\nmid P<0.05$ compared with the response to RLLFS- $\mathrm{NH}_{2}$ at the same concentration.

Up-regulation of expression of IL-8 gene in A549 cells by thrombin, trypsin, tryptase, elastase, PAR-1 and PAR-2 agonist peptides indicates that IL-8 released from A549 cells induced by these stimuli is most likely being newly generated, rather than pre-stored in the cells. The observation that relatively small quantity of IL-8 was released during the first $2 \mathrm{~h}$ of incubation in response to the above stimuli also supports our view. While the influence of tryptase and trypsin on IL-8 gene expression does not appear to have been studied previously, the report which found elastase [36,37] and thrombin [38] up-regulated IL8 gene expression in human epithelial cells may support our current findings. To our knowledge, this is the first work examining IL-8 gene expression in response to sev-
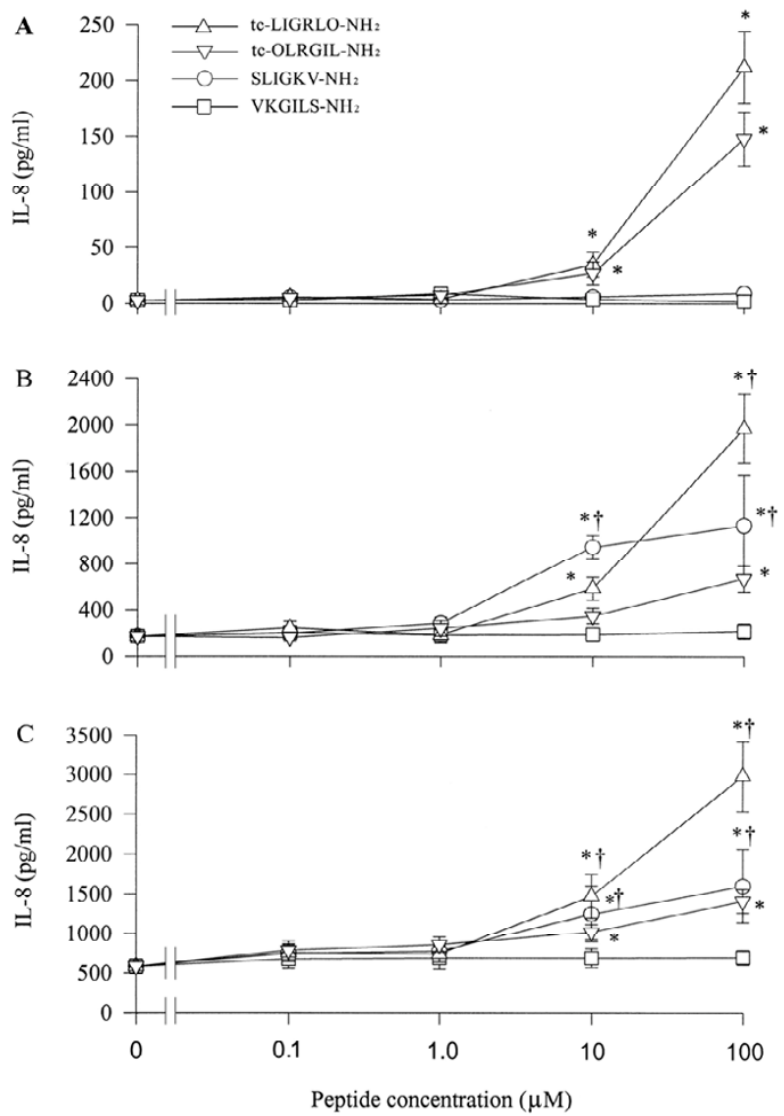

\section{Figure 6}

Effect of PAR-2 agonist peptides tc-LIGRLO-NH ${ }_{2}$ and SLIGKV-NH ${ }_{2}$ and their reverse peptides, tc-OLRGIL and VKGILS-NH ${ }_{2}$ on IL-8 release from A549 cells. Cells were incubated with various concentrations of tc-LIGRLO-NH (open triangle), tc-OLRGIL (open reverse triangle), SLIGKV$\mathrm{NH}_{2}$ (open circle) or VKGILS-NH $\mathrm{NH}_{2}$ (open square) at $37^{\circ} \mathrm{C}$ for (A) $2 \mathrm{~h}$, (B) $8 \mathrm{~h}$ and (C) $16 \mathrm{~h}$. Values shown are Mean $\pm \mathrm{SE}$ for five separate experiments performed in duplicate. $* P<$ 0.05 compared with the response to medium alone control; $t P<0.05$ compared with the response to the corresponding reverse peptide at the same concentration.

eral serine proteinases in epithelial cells under the same conditions. The parallel investigation of the actions of serine proteinases on A549 cells may contribute to easier understanding of the role of these proteinases in regulation of IL- 8 gene expression. It is difficult to understand the reason why GYPGQV-NH ${ }_{2}$ does not significantly upregulate IL-8 gene expression, but stimulates IL-8 release from A549 cells at $16 \mathrm{~h}$ following incubation. It could be that the significantly increased IL- 8 gene expression occurs between 8 and $16 \mathrm{~h}$ incubation period, but we did not examine it. 

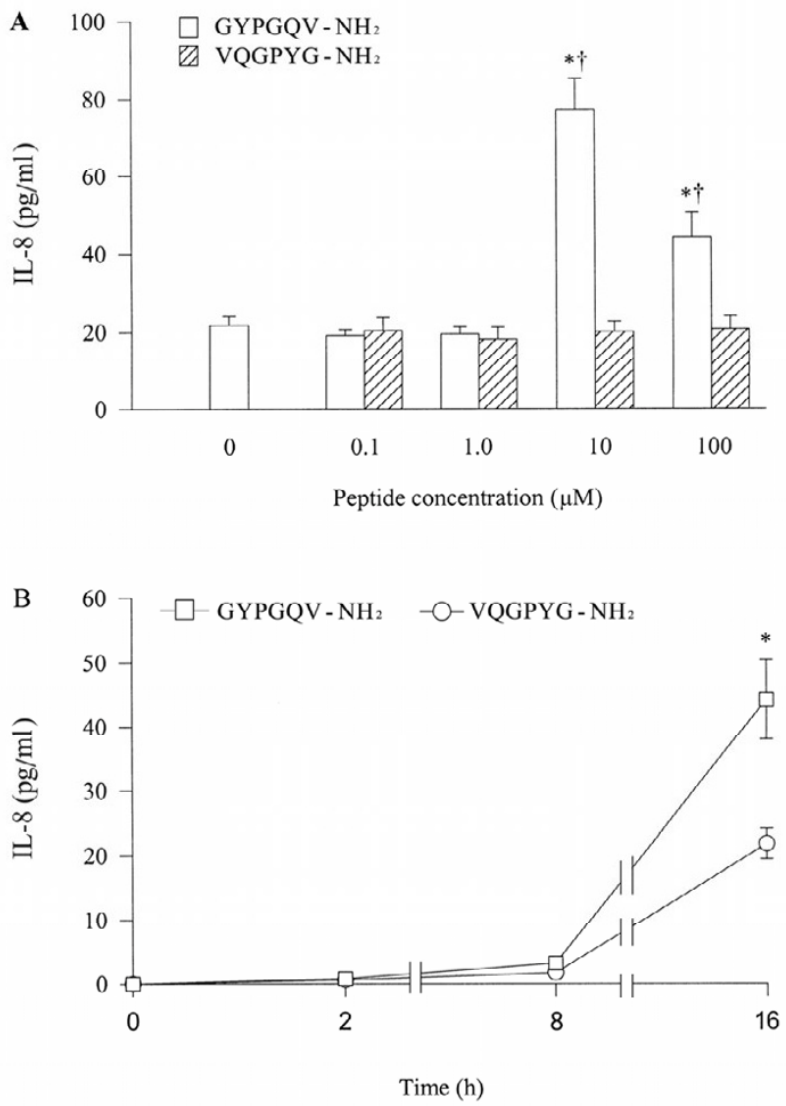

\section{Figure 7}

Effect of GYPGQV-NH ${ }_{2}$, a PAR-4 agonist peptide and its reverse peptide VQGPYG-NH $\mathrm{N}_{2}$ on release of IL-8 from A549 cells. Cells were incubated with various concentrations of GYPGQV-NH $\mathrm{H}_{2}$ or VQGPYG- $\mathrm{NH}_{2}$ at $37^{\circ} \mathrm{C}$ for $16 \mathrm{~h}(\mathrm{~A})$, or with $10 \mu \mathrm{M}$ of GYPGQV-NH $\mathrm{N}_{2}$ for $2 \mathrm{~h}, 8 \mathrm{~h}$ and $16 \mathrm{~h}$ (B). Values shown are mean $\pm \mathrm{SE}$ for 5 separate experiments. $* P<$ 0.05 compared with the response to medium alone control; tP $<0.05$ compared with the response to VQGPYG-NH $\mathrm{N}_{2}$ at the same concentration.

Induction of inflammatory mediator release from airway epithelial cells by agonists of PARs has been demonstrated previously. Thus, agonist of PAR-1 stimulated plateletderived growth factor secretion from lung epithelial cells [39]; agonists of PAR-2 stimulated IL-8 secretion from 16 HBE cells [40], GM-CSF and eotaxin release from human pulmonary epithelial cells [41] and matrix metalloproteinase-9 release from A549 and primary cultured small airway epithelial cells [42], and agonist of PAR-4 stimulated IL-8 secretion from human respiratory epithelial cells [8].

Our findings further strengthen the view that through activation of PARs, serine proteinases are actively involved in the pathogenesis of airway inflammation.

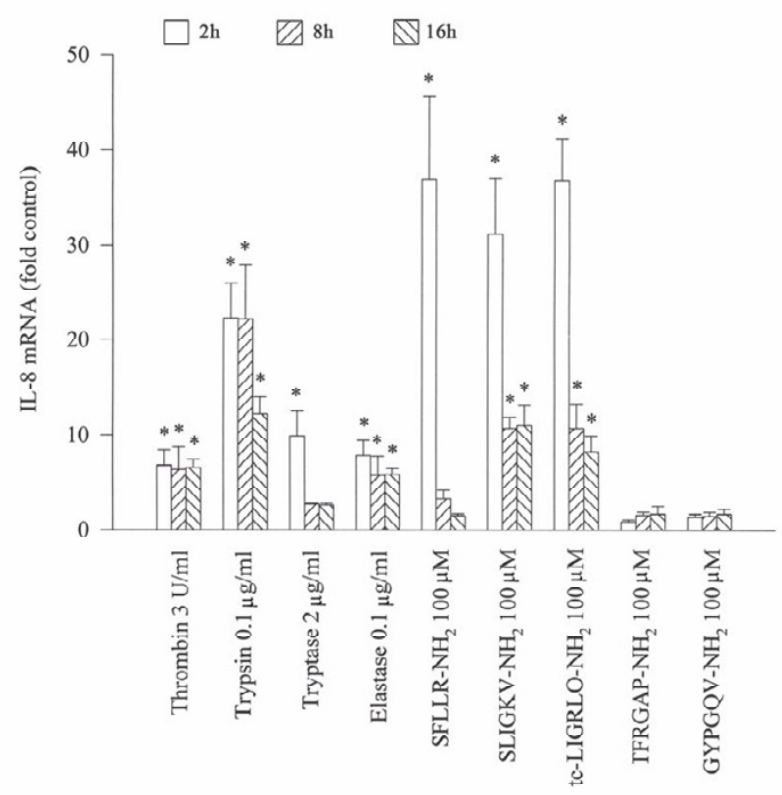

Figure 8

Effect of serine proteinases and agonist peptides of PARs on the expression of IL-8 mRNA in A549 cells. Total cellular RNA was isolated, reverse transcribed to CDNA, and the cDNA was used for real-time PCR. Cells were treated with the testing compounds at $37^{\circ} \mathrm{C}$ for 2 (open bars), 8 (left hatched bars) and $16 \mathrm{~h}$ (right hatched bars), respectively. The data were normalized to the housekeeping gene $(\beta$-actin gene) and were expressed as mean \pm SE fold of control for three separate experiments performed in duplicate. ${ }^{*} p<$ 0.05 compared with the baseline control.

However, since A549 cells is not a normal airway epithelial cells, it may not fully represent the events happening in normal airway epithelial cells in response to the stimuli above in real life.

\section{Conclusion}

serine proteinases tested are potent stimuli of IL-8 secretion from A549 cells, and the influence of these proteinases on airway epithelial cells are most likely through activation of PARs. Induction of IL-8 secretion by proteinases indicates that they are likely to contribute to the pathogenesis of airway inflammatory disorders.

Development of proteinase inhibitor drugs may be valuable for treatment of these diseases.

\section{Methods \\ Reagents}

Human thrombin, trypsin, soybean trypsin inhibitor (SBTI), $\alpha_{1}$-antitrypsin, leupeptin, benzamidine, paraformaldehyde and bovine serum albumin (BSA, fraction V) were all Sigma products. Nonenzymatic cell dissociation 
solution (CDS) was obtained from Sigma-Aldich (St Louis, MO, USA). Recombinant hirudin, human neutrophil elastase and MeOSuc-Ala-Ala-Pro-Ala-CMK (MSACK) were obtained from Calbiochem (San Diego, CA, USA). Recombinant human Lung $\beta$ tryptase was from Promega (Madison, WI, USA). Agonist peptides of PARs, as well as their reverse forms were synthesized (CL Bio-Scientific Inc, Xi An, China). The sequences of the active and control peptides, respectively, were: PAR-1, SFLLR-NH $\mathrm{N}_{2}$ and RLLFS-NH ${ }_{2} ;$ PAR-2, SLIGKV-NH ${ }_{2}$ and VKGILS-NH ${ }_{2}$ as well as trans-cinnamoyl (tc)-LIGRLO- $\mathrm{NH}_{2}$ and tcOLRGIL-NH $\mathrm{H}_{2}$; PAR-3, TFRGAP-NH $\mathrm{N}_{2}$ and PAGRFT-NH $\mathrm{H}_{2}$; PAR-4, GYPGQV-NH $\mathrm{H}_{2}$ and VQGPYG-NH . Tissue culture reagents were purchased from GIBCO (Carlsbad, CA, USA) and Sigma Inc. Human IL-8 ELISA kits were purchased from R\&D Systems (Minneapolis, MN). TRIzol Reagent was from Invitrogen (Carlsbad, CA, USA). The RNA-PCR kit was from TaKaRa (DaLian, China). SYBR Green I Nucleic Acid Gel Stain was from BMA Inc (USA). PE-conjugated mouse anti-human PAR-1 monoclonal and FITC- conjugated mouse anti-human PAR-2 monoclonal antibodies, anti-PAR-3 and anti-PAR- 4 rabbit polyclonal IgGs were purchased from Santa Cruz Biotechnology (Santa Cruz, CA, USA). FITC-conjugated goat anti-rabbit polyclonal antibody was from BD Pharmingen (San Jose, CA, USA). Platinum ${ }^{\circledast}$ SYBR $^{\circledast}$ Green qPCR kit and Superscript ${ }^{\oplus}$ First Strand System were from invitrogen Corp. (Carlsbad, CA, USA). Most of other reagents such as salt and buffer components were analytical grade and obtained from Sigma (St. Louis, MO, USA). The human lung carcinoma cell line A549 (Morphology: epithelial) was obtained from the American Type Culture Collection (Manassas, VA, USA).

\section{Cell cultures}

A549 cells were grown in Dulbecco's modified Eagle's medium (DMEM), supplemented with $10 \%(\mathrm{v} / \mathrm{v})$ fetal calf serum (FCS), $100 \mathrm{U} / \mathrm{ml}$ penicillin and $100 \mu \mathrm{g} / \mathrm{ml}$ streptomycin. Cells were cultured in $75-\mathrm{cm}^{2}$ tissue culture flasks (Falcon) at $37^{\circ} \mathrm{C}$ in a $5 \%(\mathrm{v} / \mathrm{v}) \mathrm{CO}_{2}$, water-saturated atmosphere.

\section{Stimulation of epithelial cells}

Cells were detached from culture flasks using trypsin, seeded into 12-well tissue culture plates, and grown to about $80 \%$ confluence. The cells were then cultured with the serum-free basal medium for an additional $16 \mathrm{~h}$ before challenge. For challenge experiments, cells were exposed to various concentrations of thrombin $(0.01-10$ $\mathrm{U} / \mathrm{ml}, 1 \mathrm{U} / \mathrm{ml}=5.6 \mathrm{nM})$, trypsin $(1-300 \mathrm{ng} / \mathrm{ml}, 1 \mu \mathrm{g} / \mathrm{ml}$ $=42 \mathrm{nM})$, tryptase $(0.125-2 \mu \mathrm{g} / \mathrm{ml}, 1 \mu \mathrm{g} / \mathrm{ml}=7.4 \mathrm{nM})$, elastase $(0.01-0.6 \mu \mathrm{g} / \mathrm{ml}, 1 \mu \mathrm{g} / \mathrm{ml}=34 \mathrm{nM})$ and their peptidase inhibitors, respectively, and also to PAR-1, PAR2, PAR-3 and PAR-4 agonist peptides, as well as their reverse peptides $(0.1-100 \mu \mathrm{M})$, respectively. Culture supernatants ( $1 \mathrm{ml}$ per well) were collected at different times $(2 \mathrm{~h}, 8 \mathrm{~h}, 16 \mathrm{~h})$, centrifuged at $4{ }^{\circ} \mathrm{C}$, and stored at $80^{\circ} \mathrm{C}$ until use. Concentrations of IL- 8 in the A549 culture supernatants were quantified using commercial specific ELISA kits according to the manufacturer's instructions.

\section{Identification of expression of mRNA of PARs}

The expression of mRNA of PARs by A549 cells was investigated with RT-PCR technique. Total RNA was isolated using TRIzol reagent according to the manufacturer's instructions. Briefly, cells were lysed directly by adding 1 $\mathrm{ml}$ of TRIzol Reagent to a $3.5 \mathrm{~cm}$ diameter dish $(1 \mathrm{ml}$ per $10 \mathrm{~cm}^{2}$ ). A total of $200 \mu \mathrm{l}$ of chloroform was added, and tubes were then centrifuged at $12,000 \mathrm{~g}$ for $15 \mathrm{~min}$ at $4{ }^{\circ} \mathrm{C}$, after which the aqueous phase was transferred to new tubes, RNA was precipitated by adding $0.5 \mathrm{ml}$ of isopropyl alcohol, and then centrifuged at $12,000 \mathrm{~g}$ for $10 \mathrm{~min}$ at $4{ }^{\circ} \mathrm{C}$. Finally, $1 \mathrm{ml}$ of $75 \%(\mathrm{v} / \mathrm{v})$ ethanol was added to the pelleted RNA, and centrifuged at $7,500 \mathrm{~g}$ for $5 \mathrm{~min}$ at $4^{\circ} \mathrm{C}$. Total RNA was quantified by measuring absorbance ratios at $260 / 280 \mathrm{~nm}$. CDNA was prepared by reverse transcriptase using a commercial RNA-PCR kit, and reactions were performed according to the manufacturer's instructions. For each reaction, $1 \mu \mathrm{g}$ of total RNA was reversely transcribed using oligo-d (T) and PAR-4 RT primers according to the protocol. The cDNA was amplified using forward and reverse specific primers for amplifying human PARs. $\beta$-actin was used as an internal control. Primers for PAR-1, PAR-2 and PAR-3 were designed based on PAR sequences in Genbank using Omiga software; Primer for PAR-4 was designed as described by Kahn et al [26]. Primers were prepared by Invitrogen Biotechnology Co., Ltd. The primer sequences were summarized in Table 1 . The conditions for amplification were: for PAR-1, PAR2, and PAR-3, the PCR mixture was heated at $94^{\circ} \mathrm{C}$ for 2 min followed by 35 cycles at $94^{\circ} \mathrm{C}$ for $30 \mathrm{sec}, 67^{\circ} \mathrm{C}$ for 30 sec, $72^{\circ} \mathrm{C}$ for $1 \mathrm{~min}$ and $72^{\circ} \mathrm{C}$ for $10 \mathrm{~min}$ for 1 cycle; for PAR- 4 and $\beta$-actin, the PCR mixture was heated at $94^{\circ} \mathrm{C}$ for $2 \mathrm{~min}$ followed by $35 \mathrm{cycles}$ at $94^{\circ} \mathrm{C}$ for $30 \mathrm{sec}, 55^{\circ} \mathrm{C}$ for $30 \mathrm{sec}, 72^{\circ} \mathrm{C}$ for $30 \mathrm{sec}$ and $72^{\circ} \mathrm{C}$ for $10 \mathrm{~min}$ for 1 cycle. Electrophoresis was conducted in 1.5\% agarose gels that were stained with SYBR Green I Nucleic Acid Gel Stain and photographed under UV light. PCR products were then sequenced.

\section{Quantitative real-time PCR}

IL-8 mRNA expression in A549 cells was determined by real-time PCR following the manufacture's protocol. Briefly, total RNA was isolated from the stimulated A549 cells using TRIzol Reagent. cDNA was synthesized from 5 $\mu \mathrm{g}$ of total RNA by using Superscript first strand synthesis system for RT-PCR and oligo-dT primers. A doublestranded DNA binding dye method was used for quantitative PCR/RT-PCR. Real-time PCR was performed in the ABI Prism 7700 Sequence Detection System (Perkin Elmer 
Applied Systems, Foster City, CA, USA) using the Platinum SYBR Green I PCR kit [each reaction containing 12.5 $\mu \mathrm{l}$ of $2 \times$ SYBR green Master Mix, $300 \mathrm{nM}$ of primers $[43,44], 5 \mu \mathrm{l}$ of a $1: 10$ dilution of the cDNA or plasmid DNA and water to a total of $25 \mu \mathrm{l}]$. The thermal cycling conditions included an initial denaturation step at $95^{\circ} \mathrm{C}$ for $2 \mathrm{~min}, 40$ cycles at $95^{\circ} \mathrm{C}$ for $15 \mathrm{~s}, 60^{\circ} \mathrm{C}$ for $30 \mathrm{~s}$, and $72^{\circ} \mathrm{C}$ for $30 \mathrm{~s}$. Consequently, at the end of the PCR cycles, the real-time PCR products were immediately analyzed using a ramping rate of $0.03^{\circ} \mathrm{C} / \mathrm{s}$ from 60 to $95^{\circ} \mathrm{C}$ to calculate the dissociation curve to verify the correctness of the amplicons. None-template controls for each primer pair were also included on each reaction plate to check for external DNA contamination. Sequence-specific standard curves were generated using 10 -fold serial dilutions of plasmid DNA $\left(10^{4} \sim 10^{9}\right.$ copies), and then the values for the initial concentrations of unknown samples were calculated by using the software (version 1.7) provided with the ABI 7700 system. IL-8 mRNA expression in each sample was finally determined after correction with $\beta$-actin expression. Each measurement of a sample was conducted in duplicate.

\section{Flow cytometry analysis}

Adherent A549 cells were detached from culture flasks using the cell dissociation solution. Cells were pelleted by centrifugation, fixed with $2 \%$ paraformaldehyde, and resuspended in 1\% BSA/PBS. Cells were incubated directly with 1 in 20 dilution of PE-conjugated mouse anti-human PAR-1 monoclonal and FITC-conjugated mouse anti-human PAR-2 monoclonal antibodies for 30 min on ice, followed by two washes with $1 \%$ BSA/PBS. For PAR-3 and PAR-4 staining, cells were incubated with 1 in 20 dilution of rabbit polyclonal antibodies for a period of $30 \mathrm{~min}$ on ice. After two washes with $1 \%$ BSA/PBS, immunofluorescence staining was performed with 1 in 100 dilution FITC-conjugated goat anti-rabbit polyclonal antibodies for $30 \mathrm{~min}$ on ice. Finally, cells were resuspended in PBS and labeled cells were analyzed on a FACS Calibur flow cytometer with the use of CellQuest software (BD Biosciences). For staining cytoplasmic PARs, A549 cells were permeabilized with $0.2 \%$ Triton X-100 for 5 min at room temperature.

\section{Immunofluorescence cell staining}

A549 cells were seeded onto 8 chamber microscope slides (Nalgene Nunc chamber slides) and allowed them to adhere overnight. The cells were then washed with PBS with $1 \%$ BSA followed by fixation in methanol for $20 \mathrm{~min}$ on ice. After which the cells were incubated for $5 \mathrm{~min}$ with the same wash buffer. Cells were stained directly with 1 in 20 dilution of PE-conjugated mouse anti-human PAR-1 and PAR-2 monoclonal antibodies for $1 \mathrm{~h}$ at room temperature and followed by three 1 min washes with $1 \%$ BSA/PBS. For PAR-3 and PAR-4 staining, cells were incu- bated with 1 in 20 dilution of rabbit polyclonal IgG antibodies for a period of $1 \mathrm{~h}$ at room temperature and followed by three 1 min washes with $1 \%$ BSA/PBS. A FITC-conjugated goat anti-rabbit polyclonal antibody was then added for $1 \mathrm{~h}$ at room temperature and followed by a further $1 \%$ BSA/PBS wash. Images were obtained on a Nikon EZ-C1 confocal laser scanning microscope (Japan).

\section{Determination of IL-8, IL-I 0, IL-I6, IL-I 7 and IL-I8}

IL-8, IL-10, IL-16, IL-17 and IL-18 release was measured by using ELISA kits according to the manufacturer's instruction.

\section{Statistics}

Data are expressed as mean \pm SEM for the indicated number of independently performed duplicated experiments. Statistical significance between means was analyzed by one-way ANOVA or the Student's $t$ test utilizing the SPSS11.0 version. $P<0.05$ was taken as statistically significant.

\section{Abbreviations}

protease-activated receptors (PARs); granulocyte-macrophage colony stimulating factor (GM-CSF); soybean trypsin inhibitor (SBTI); MeOSuc-Ala-Ala-Pro-Ala-CMK (MSACK); trans-cinnamoyl (tc)

\section{Authors' contributions}

HW carried out the most of experimental work and drafted the Material and Method of the manuscript and supplied all analyzed data.

YZ served as a research assistant and participated in the cellular experiments, ELISA assay and RT-PCR experiments.

SH raised the funds, designed and coordinated the study, sorted out technical problems in the study and wrote the major part of the manuscript.

All authors read and approved the final manuscript.

\section{Acknowledgements}

We are grateful to Professor Bill Orr (Department of Pathology, the University of Manitoba, Canada) for his critical reading of the manuscript. We would like to also give our thanks to Miss Yiling Fu and Miss Zeman Fang and for their excellent technical support throughout the study. This project is supported by the grants from the $\mathrm{Li} \mathrm{Ka}$ Shing Foundation, Hong Kong, China (No. C020000I); the Major State Basic Research Program of China (973 Program) (No. 200ICB5 10009); the National Natural Science Foundation of China (No. 3047160I; 30570813); the Planned Science and Technology Project of Guang Dong Province, China (No. 2003B3 I502) and the National Natural Science Foundation of Guang Dong Province, China (No. 04 I06 I22). 


\section{References}

I. Cromwell O, Hamid Q, Corrigan CJ, Barkans J, Meng Q, Collins PD, $\mathrm{Kay} A B$ : Expression and generation of interleukin (IL)-8, IL-6 and granulocyte-macrophage colony-stimulating factor by bronchial epithelial cells and enhancement by IL-I $\beta$ and tumor necrosis factor- $\alpha$. Immunology 1992, 77:330-337.

2. Stellato C, Beck LA, Gorgone GA, Proud D, Schall TJ, Ono SJ, Lichtenstein LM, Schleimer RP: Expression of the chemokine RANTES by a human bronchial epithelial cell line: modulation by cytokines and glucocorticoids. J Immunol 1995 I 55:4|0-4|8.

3. Krishna MT, Chauhan A, Little L, Sampson K, Hawksworth R, Mant T, Djukanovic R, Lee T, Holgate ST: Inhibition of mast cell tryptase by inhaled APC366 attenuates allergen-induced late-phase airway obstruction in asthma. J Allergy Clin Immunol 2001, 1 07: 1039-1045.

4. Terada M, Kelly EA, Jarjour NN: Increased thrombin activity after allergen challenge: a potential link to airway remodeling? Am J Respir Crit Care Med 2004, I 69:373-377.

5. Monteseirin J, Bonilla I, Camacho MJ, Chacon P, Vega A, Chaparro A Conde J, Sobrino F: Specific allergens enhance elastase release in stimulated neutrophils from asthmatic patients. Int Arch Allergy Immunol 2003, I 3 I: I74- I8I.

6. Swystun VA, Gordon JR, Davis EB, Zhang X, Cockcroft DW: Mast cell tryptase release and asthmatic responses to allergen increase with regular use of salbutamol. J Allergy Clin Immunol 2000, 106:57-64.

7. Tonnel $A B$, Gosset P, Tillie-Leblond I: Characteristics of the Inflammatory response in bronchial lavage fluids from patients with status asthmaticus. Int Arch Allergy Immunol 2001 , I 24:267-27I.

8. Asokananthan N, Graham PT, Fink J, Knight DA, Bakker AJ, McWilliam AS, Thompson PJ, Stewart GA: Activation of protease-activated receptor (PAR)-I, PAR-2, and PAR-4 stimulates IL-6, IL-8, and prostaglandin E2 release from human respiratory epithelial cells. J Immunol 2002, I 68:3577-3585

9. Uehara A, Muramoto K, Takada H, Sugawara S: Neutrophil serine proteinases activate human nonepithelial cells to produce inflammatory cytokines through protease-activated receptor 2. J Immunol 2003, I 70:5690-5696.

10. Reid DW, Ward C, Wang N, Zheng L, Bish R, Orsida B, Walters EH: Possible anti-inflammatory effect of salmeterol against interleukin-8 and neutrophil activation in asthma in vivo. Eur Respir J 2003, 21 :994-999.

II. Vu TK, Hung DT, Wheaton VI, Coughlin SR: Molecular cloning of a functional thrombin receptor reveals a novel proteolytic mechanism of receptor activation. Cell I99I, 64:I057-1068.

12. Molino M, Barnathan ES, Numerof R, Clark J, Dreyer M, Cumashi A, Hoxie JA, Schechter NM, Woolkalis M, Brass LF: Interactions of mast cell tryptase with thrombin receptors and PAR-2. J Biol Chem 1997, 272:4043-4049.

13. Schmidt VA, Nierman WC, Maglott DR, Cupit LD, Moskowitz KA, Wainer JA, Bahou WF: The human proteinase-activated receptor-3 (PAR-3) gene: identification within a PAR gene cluster and characterization in vascular endothelial cells and platelets. J Biol Chem 1998, 273:1506I-15068.

14. Xu WF, Andersen H, Whitmore TE, Presnell SR, Yee DP, Ching A, Gilbert T, Davie EW, Foster DC: Cloning and characterization of human protease-activated receptor 4. Proc Natl Acad Sci USA 1998, 95:6642-6646.

15. He S, Aslam A, Gaca MD, He Y, Buckley MG, Hollenberg MD, Walls AF: Inhibitors of tryptase as mast cell-stabilizing agents in the human airways: effects of tryptase and other agonists of proteinase-activated receptor 2 on histamine release. J Pharmacol Exp Ther 2004, 309: I19-126.

16. Ozen J, Atay A, Beydemir B, Serdar MA, Ural AU, Dalkiz M, Soysal Y: In vitro IL-I beta release from gingival fibroblasts in response to pure metals, dental alloys and ceramic. J Oral Rehabil 2005, 32:511-517.

17. Uehara A, Sugawara Y, Sasano T, Takada H, Sugawara S: Proinflammatory cytokines induce proteinase 3 as membrane-bound and secretory forms in human oral epithelial cells and antibodies to proteinase 3 activate the cells through proteaseactivated receptor-2. J Immunol 2004, I 73:4I79-4I89.

18. Kinoshita M, Okada M, Hara M, Furukawa Y, Matsumori A: Mast Cell Tryptase in Mast Cell Granules Enhances MCP-I and Inter- leukin-8 Production in Human Endothelial Cells. Arterioscler Thromb Vasc Biol 2005, 25: I858-1863.

19. Coughlin SR, Camerer E: PARticipation in inflammation. J Clin Invest 2003, I I I:25-27.

20. Dulon S, Cande C, Bunnett NW, Hollenberg MD, Chignard M, Pidard $D$ : Proteinase-activated receptor-2 and human lung epithelial cells: disarming by neutrophil serine proteinases. $\mathrm{Am} J$ Respir Cell Mol Biol 2003, 28:339-346.

21. Broide DH, Gleich G], Cuomo AJ, Coburn DA, Federman EC Schwartz LB, Wasserman SI: Evidence of ongoing mast cell and eosinophil degranulation in symptomatic asthma airway. J Allergy Clin Immunol 1991, 88:637-648.

22. Fahy JV, Kim KW, Liu J, Boushey HA: Prominent neutrophilic inflammation in sputum from subjects with asthma exacerbation. I Allergy Clin Immunol 1995, 95:843-852.

23. Tsuchihashi S, Yasuoka S, Terao T, Yoshinaga T, Kawano S, Takegawa Y, Kurokawa M, Doi H, Nakayama T: Fibrinogenolytic activity of a novel trypsin-like enzyme found in human airways. Nihon Kyobu Shikkan Gakkai Zasshi 1997, 35:49-55.

24. Higashimoto $Y$, Yamagata $Y$, Iwata T, Ishiguchi T, Okada M, Masuda $M$, Satoh H, Itoh H: Adenoviral EI A suppresses secretory leukoprotease inhibitor and elafin secretion in human alveolar epithelial cells and bronchial epithelial cells. Respiration 2005 , 72:629-635.

25. Berger P, Compton SJ, Molimard M, Walls AF, N'Guyen C, Marthan $\mathrm{R}$, Tunon-De-Lara JM: Mast cell tryptase as a mediator of hyperresponsiveness in human isolated bronchi. Clin Exp Allergy 1999 , 29:804-812

26. Kahn ML, Nakanishi-Matsui M, Shapiro MJ, Ishihara $H$, Coughlin SR: Protease-activated receptors $I$ and 4 mediate activation of human platelets by thrombin. J Clin Invest 1999, 103:879-887.

27. O'Brien PJ, Prevost N, Molino M, Hollinger MK, Woolkalis MJ, Woulfe DS, Brass LF: Thrombin responses in human endothelial cells: contributions from receptors other than PARI include the transactivation of PAR2 by thrombin-cleaved PARI. J Biol Chem 2000, 275:13502-13509.

28. Bachli EB, Pech CM, Johnson KM, Johnson DJ, Tuddenham EG, McVey $\mathrm{JH}$ : Factor $\mathrm{Xa}$ and thrombin, but not factor VIla, elicit specific cellular responses in dermal fibroblasts. J Thromb Haemost 2003, I: 1935-1944.

29. Bretschneider E, Spanbroek R, Lotzer K, Habenicht AJ, Schror K: Evidence for functionally active protease-activated receptor-3 (PAR-3) in human vascular smooth muscle cells. Thromb Haemost 2003, 90:704-709.

30. Brass LF, Molino M: Protease-activated G protein-coupled receptors on human platelets and endothelial cells. Thromb Haemost 1997, 78:234-24I.

3I. Ossovskaya VS, Bunnett NW: Protease-activated receptors: contribution to physiology and disease. Physiol Rev 2004, 84:579-621.

32. Nystedt S, Emilsson K, Larsson AK, Strombeck B, Sundelin J: Molecular cloning and functional expression of the gene encoding the human proteinase-activated receptor 2. Eur J Biochem 1995, 232:84-89.

33. Vergnolle N, MacNaughton WK, Al-Ani B, Saifeddine M, Wallace JL, Hollenberg MD: Proteinase-activated receptor 2 (PAR2)-activating peptides: identification of a receptor distinct from PAR2 that regulates intestinal transport. Proc Natl Acad Sci USA 1998, 95:7766-777|.

34. Ishihara H, Connolly AJ, Zeng D, Kahn ML, Zheng YW, Timmons C, Tram T, Coughlin SR: Protease-activated receptor 3 is a second thrombin receptor in humans. Nature 1997, 386:502-506.

35. Kahn ML, Zheng YW, Huang W, Bigornia V, Zeng D, Moff S, Farese RV Jr, Tam C, Coughlin SR: A dual thrombin receptor system for platelet activation. Nature 1998, 394:690-694.

36. Walsh DE, Greene CM, Carroll TP, Taggart CC, Gallagher PM, O'Neill SI, McElvaney NG: Interleukin-8 up-regulation by neutrophil elastase is mediated by MyD88/IRAK/TRAF-6 in human bronchial epithelium. J Biol Chem 2001, 276:35494-35499.

37. Chen HC, Lin HC, Liu CY, Wang CH, Hwang T, Huang TT, Lin CH, Kuo HP: Neutrophil elastase induces IL-8 synthesis by lung epithelial cells via the mitogen-activated protein kinase pathway. J Biomed Sci 2004, I I :49-58.

38. Scholz M, Vogel JU, Hover G, Kotchetkov R, Cinatl J, Doerr HW, Cinatl J: Thrombin stimulates IL-6 and IL-8 expression in 
cytomegalovirus-infected human retinal pigment epithelial cells. Int J Mol Med 2004, 13:327-331.

39. Shimizu S, Gabazza EC, Hayashi T, Ido M, Adachi Y, Suzuki K: Thrombin stimulates the expression of PDGF in lung epithelial cells. Am J Physiol Lung Cell Mol Physiol 2000, 279:L503-L5IO.

40. Page K, Strunk VS, Hershenson MB: Cockroach proteases increase IL-8 expression in human bronchial epithelial cells via activation of protease-activated receptor (PAR)-2 and extracellular-signal-regulated kinase. J Allergy Clin Immunol 2003, II 2: III2-III8.

41. Sun G, Stacey MA, Schmidt M, Mori L, Mattoli S: Interaction of mite allergens Der $\mathrm{p} 3$ and Der $\mathrm{p} 9$ with protease-activated receptor-2 expressed by lung epithelial cells. J Immunol 200I, 167:1014-1021.

42. Vliagoftis $H$, Schwingshackl A, Milne CD, Duszyk M, Hollenberg MD, Wallace JL, Befus AD, Moqbel R: Proteinase-activated receptor2-mediated matrix metalloproteinase-9 release from airway epithelial cells. J Allergy Clin Immunol 2000, I06:537-545.

43. Ohki R, Yamamoto K, Mano H, Lee RT, Ikeda U, Shimada K: Identification of mechanically induced genes in human monocytic cells by DNA microarrays. J Hypertens 2002, 20:685-691.

44. Lin P, Hu SW, Chang TH: Correlation between gene expression of aryl hydrocarbon receptor (AhR), hydrocarbon receptor nuclear translocator (Arnt), cytochromes P450IAI (CYPIAI) and IBI (CYPIBI), and inducibility of CYPIAI and CYPIB I in human lymphocytes. Toxicol Sci 2003, 7 I:20-26.

Publish with Bio Med Central and every scientist can read your work free of charge

"BioMed Central will be the most significant development for disseminating the results of biomedical research in our lifetime. "

Sir Paul Nurse, Cancer Research UK

Your research papers will be:

- available free of charge to the entire biomedical community

- peer reviewed and published immediately upon acceptance

- cited in PubMed and archived on PubMed Central

- yours - you keep the copyright 